\title{
Environmental Effects of International Tourism in Mediterranean European Countries: a Panel Cointegration and Causality Analysis
}

\author{
Yilmaz Bayar $^{1 *}$, Emre Sakar $^{2}$, Tugba Betul Ozav ${ }^{3}$ \\ ${ }^{1}$ Bandirma Onyedi Eylul University, Faculty of Economics and Administrative Sciences, \\ Department of Public Finance, Bandirma/Balikesir, Turkey \\ ${ }^{2}$ Usak University, Faculty of Economic and Administrative Sciences, Department of Public Finance, Usak-Turkey \\ ${ }^{3}$ Izmir Katip Celebi University, Institute of Social Sciences, Izmir-Turkey
}

Received: 28 May 2020

Accepted: 2 August 2020

\begin{abstract}
Tourism sector has become one of the largest export items in the globalized world and in turn an item of national income for the countries. However, the globally expanding tourism sector may lead to negative impacts such as environmental degradation, and detrimental effects on social and cultural values despite its positive effects on economic growth, employment, and balance of payments. In the study, we explore the short and long run effects of international tourism and real gross domestic product on environment proxied by carbon dioxide emissions in Mediterranean European states over the period of 1995-2018, using second generation cointegration and causality tests. The short run analysis revealed a one-way causality from real gross domestic product to carbon dioxide emissions. Furthermore, the long run analysis indicated that international tourism had a positive influence on carbon dioxide emissions in Italy and Slovenia and real gross domestic product had a positive influence on carbon dioxide emissions in most of the countries in the sample.
\end{abstract}

Keywords: international tourism, economy's size, environment, panel cointegration analysis, panel causality analysis

\section{Introduction}

International tourism has been raised considerably through affordable international travel costs, visa and other requirements facilitation, technological progress, and improvements in living standards in turn international tourist arrivals globally reached 1.5 billion

*e-mail: yilmaz.bayar@usak.edu.tr in 2019 [1] and total international tourism exports (the third largest export category in the world) was about USD 1.7 trillion in 2018 [2]. The tourism sector has become one of the crucial economic sectors in parallel with the aforementioned developments. Furthermore, tourism sector is an important component of national income and a significant source of foreign exchange [3] and it also makes a significant contribution to the employment due to its labor intensive structure.

However, the expanding tourism sector can include negative economic, social, cultural, and 
environmental effects. In the study, we analyze the environmental effects of tourism sector considering the related literature. The tourism sector may make a positive contribution to the environmental degradation through changing the composition of flora and fauna species, pollution, and erosion [4]. In this context, the widespread use of tourism transportation increases the release of fossil resources into the nature and increases the ecological footprint, leaving destructive effects on the environment. The construction of tourist attraction centers can negatively affect the geological landscape and soil structure. Furthermore, blasting land masses to create new touristic areas, killing forest areas for new roads, bridges and ropeways also destroy the geological landscape of the nature. Touristic travels to the natural structures can adversely affect nature, animals and plants if necessary precautions are not taken. The raising number of tourists in attraction centers can lead increases in the artificial urbanization, commercialization, natural structures, energy and water consumption [5]. However, tourism sector development has potential to positively affect the environment through the development of infrastructure services, the raising income of local people, and the improvements in the environmental awareness. On the other side, the influence of economic growth on environment is generally expressed by employing the EKC (environmental Kuznets curve) hypothesis. The hypothesis suggests that economic growth initially leads to a damaging effect on the environment, but economic growth causes to environmental improvements after achievement of a certain threshold of economic growth [6].

The European region is the most travelled region in the world and attracted about half of the international arrivals in 2018, and in turn gained $40 \%$ of international tourism receipts [2]. The Mediterranean Europe accounts for the $40.8 \%$ of international arrivals and $38.6 \%$ of international tourism receipts to the region. Therefore, we explore the environmental influence of international tourism and economic growth proxied by real GDP (gross domestic product) on $\mathrm{CO}_{2}$ (carbon dioxide) emissions in Mediterranean European states through second generation econometric tests. In the related literature, the environmental effects of tourism sector have been investigated for different countries and country groups, but Mediterranean European countries have not been noticed by the scholars. Therefore, the study sample is the first novelty of the paper. Secondly, nearly half of the studies investigating the environmental effects of tourism employed first generation cointegration tests and estimators disregarding cross-sectional dependence, heterogeneity, and structural breaks. So the use of second generation econometric tests in the applied section of the paper is the second potential contribution of the paper to the relevant literature. Furthermore, the paper has potential to make a contribution to the limited empirical literature about the interaction between tourism and environment.
Consequently, the study targets to make a contribution to the relevant literature in the aforementioned three ways.

The rapid and continuous development of the tourism sector during the past six decades has lead the researchers to explore the economic and non-economic effects of tourism sector. However, most of the researchers have focused on the growth, employment, foreign exchange and balance of payments effects of tourism [7-23]. The effects of the tourism sector on environmental issues have been on the agenda of both politicians and researchers for the last ten years. Therefore, we research the environmental effects of international tourism considering the limited relevant literature. The empirical literature on the environmental effects of tourism has stayed inconclusive. In this context [24-27] revealed a negative influence of tourism on $\mathrm{CO}_{2}$ emissions, but $[28,29]$ disclosed a positive influence of tourism on $\mathrm{CO}_{2}$ emissions for case of Turkey. However, most of the studies (such as [30-37]) have reached different findings depending of income level of the countries and supported tourism based EKC hypothesis.

In this context, Lee and Brahmasrene [24] researched the influence of tourism receipts on $\mathrm{CO}_{2}$ emissions in 27 EU member states over the 1988-2009 period through first generation cointegration test and regression analysis and disclosed a negative effect of tourism on $\mathrm{CO}_{2}$ emissions. Özcan et al. [25] explored the nexus between tourism revenue, the number of tourists and environmental pollution for the period of 1995-2011 in the most visited 10 countries in the world through first generation panel cointegration test and resulted that tourism negatively affected the $\mathrm{CO}_{2}$ emissions.

Akadiri et al. [26] also investigated the influence of tourism on $\mathrm{CO}_{2}$ emissions for the period of 19952013 through first generation cointegration test and regression analysis and concluded that international tourist arrivals negatively affected $\mathrm{CO}_{2}$ emissions in the long-run. Dogan and Aslan [27] examined the effect of energy consumption, real income, and tourism on carbon emission in the EU countries and candidate states over the 1995-2011 period through second generation cointegration test and revealed a negative influence of tourism on $\mathrm{CO}_{2}$ emissions.

On the other side, Katircioglu [28] investigated the interaction among environmental degradation, tourism, and energy consumption during the period of 1960-2010 in Turkey employing ARDL (Autoregressive Distributed Lag) approach and reached that tourism raised $\mathrm{CO}_{2}$ emissions. Eyuboglu and Uzar [29] also explored the interaction among $\mathrm{CO}_{2}$ emissions, economic growth, tourist arrivals, and energy consumption over the period of 1960-2014 in Turkey through different cointegration tests and revealed positive influence of tourism on $\mathrm{CO}_{2}$ emissions in both short and long-run.

On the other hand, Rasekhi et al. [30] analyzed the environmental impact of tourism in 55 developing and developed countries during the 2005-2012 period 
through regression analysis and concluded that the influence of tourism on environment was positive in developed countries, but negative in developing countries. Zhang and Gao [31] also investigated environmental effect of international tourism in China for the 1995-2011 period through first generation panel cointegration test and concluded that tourism-induced EKC hypothesis was weakly valid in western and eastern China, but invalid in central China. Zaman et al. [32] investigated the interaction among economic growth, energy demand, health expenditures, tourism development, domestic investment, and $\mathrm{CO}_{2}$ in 34 developing and developed countries for the 2005-2013 period through regression analysis and revealed a tourism-induced carbon emissions.

Paramati et al. [33] analyzed the impact of tourism on $\mathrm{CO}_{2}$ emissions and economic growth in $28 \mathrm{EU}$ states during the period of 1991-2013 through second generation cointegration test and revealed that tourism raised $\mathrm{CO} 2$ emissions in eastern $\mathrm{EU}$, but decreased $\mathrm{CO}_{2}$ emissions in western EU. On the other side, Akadiri et al. [34] explored the causal interaction among tourism, economic growth, and $\mathrm{CO}_{2}$ emissions during the period of 1995-2014 in 16 selected island countries through panel bootstrap causality test and revealed a one-way causality from tourism to $\mathrm{CO}_{2}$ emissions. Sghaier et al. [35] analyzed the long and short-term influence of tourism development on $\mathrm{CO} 2$ emissions in Morocco, Tunisia, and Egypt for the 1980-2014 period through ARDL approach and revealed that tourism had a negative influence on the environmental quality in Egypt, but had a positive effect in Morocco and Tunisia.

Balsalobre-Lorente et al. [36] investigated the longterm effect of international tourism on environment over the period of 1994-2014 in OECD countries through first and second generation cointegration tests and revealed an inverted U-shaped interaction between $\mathrm{CO}_{2}$ emissions and international tourism. Lastly, Koçak et al. [37] researched the influence of tourism on $\mathrm{CO}_{2}$ emissions in the globally most visited countries for the period of 1995 to 2014 through continuously updated fully modified and the continuously updated biascorrected estimators and revealed that tourist arrivals positively affected $\mathrm{CO}_{2}$ emissions, but tourism receipts negatively affected $\mathrm{CO}_{2}$ emissions.

The nexus about environment-economic development is one of the most empirically studied issues in the environmental economics. However, the relevant empirical literature has stayed inconclusive (e.g., [38-44]).

\section{Material and Methods}

\section{Data and Sources}

In the article, the influence of international tourism and economic growth on environment has been investigated by second generation cointegration test with structural breaks and causality test. The dependent variable environment was proxied by carbon dioxide emissions (million tonnes). On the other hand, international tourism was proxied by international tourism receipts (million US\$) and economic growth was represented by real GDP (million US\$) (constant 2010 US\$). The variable of $\mathrm{CO}_{2}$ emissions was provided from BP (British Petroleum) [45] database and the variables of international tourism and real GDP were provided from the database of World Bank [46, 47]. All the variables are annual, and the logarithmic forms of the variables were employed in the econometric analyses as seen in Table 1. Furthermore, the study period was determined as 1995-2018 due to data availability.

Mediterranean European countries were selected by regarding the classification of World Travel Organization [2], and the study sample consisted of Croatia, Cyprus, Greece, Israel, Italy, North Macedonia, Portugal, Slovenia, Spain, and Turkey. The following econometric model was formed to analyze the effect of international tourism and real GDP on the environment proxied by $\mathrm{CO}_{2}$ emissions. In this context, the limitations of the study consisted of sample size and study period. Albania, Andorra, Bosnia and Herzegovina, Malta, Montenegro, San Marino, and Serbia were excluded due to data non-availability of international tourism and $\mathrm{CO}_{2}$ emissions. Furthermore, the study period of 1995-2018 was selected to maximize the data size considering data of international tourism and $\mathrm{CO}_{2}$ emissions. Lastly, the other factors except for international tourism and real GDP was disregarded in the model, because the objective of the study is to analyze the environmental effects of inbound tourism which has considerably expanded together with globalization. The influence of international tourism and real GDP can be varied considering the relevant theoretical considerations.

$$
C O_{i t}=\beta_{0}+\beta_{1} \text { TOURISM } i t+\beta_{2} G D P_{i t}+e_{i t}
$$

Table 1. Dataset description.

\begin{tabular}{|c|c|c|}
\hline Variables & Variable description & Data source \\
\hline LCO & Carbon dioxide emissions (million tonnes) & BP [45] \\
\hline LTOURISM & International tourism receipts (million US\$) & World Bank [46] \\
\hline LRGDP & GDP (million US\$) (constant 2010 US\$) & World Bank [47] \\
\hline
\end{tabular}

Source: Authors' own elaboration. 
Table 2. Summary statistics of the dataset.

\begin{tabular}{|c|c|c|c|}
\hline Characteristics & CO & TOURISM & GDP \\
\hline Mean & 124.4896 & 15256.75 & 223168.7 \\
\hline Median & 61.45000 & 7089.500 & 2236563. \\
\hline Maximum & 472.3000 & 81250.00 & 6062.772 \\
\hline Minimum & 6.700000 & 19.00000 & 664469.9 \\
\hline Std. Dev. & 142.1066 & 17984.31 & 1.454448 \\
\hline Skewness & 1.057137 & 1.553430 & 3.750030 \\
\hline Kurtosis & 2.628362 & 4.756328 & \\
\hline
\end{tabular}

Source: Authors' own elaboration based on EViews 10.0 statistical package.

The econometric analyses were implemented through the software of EViews 10.0, Stata 14.0, and Gauss 10.0. The main characteristics of the dataset are presented in Table 2. The main characteristics revealed the considerable differences among the countries in terms of $\mathrm{CO}_{2}$ emissions, tourism sector development, and real GDP.

\section{Econometric Methodology}

In the applied section, the short and long run effects of international tourism and economic growth on environment are analyzed by second generation cointegration and causality analyses. The first generation cointegration tests disregard the presence of cross-sectional dependence among the series, in turn may yield relatively less reliable results in case of cross-sectional dependence. Therefore, employment of second generation econometric tests in presence of cross-sectional dependence leads more reliable results. For this reason, the cointegration relationship among international tourism, $\mathrm{CO}_{2}$ emissions, and real GDP is analyzed through the Westerlund and Edgerton [48] cointegration test with structural breaks. Westerlund and Edgerton [48] cointegration test takes in consideration of both cross-sectional dependence and heterogeneity together with the structural break, heteroscedasticity, and autocorrelation. The test statistics of cointegration test are calculated based on the following two equations:

$$
\begin{gathered}
y_{i t}=\propto_{i}+\psi_{i} t+\delta_{i} D_{i t}+\beta_{i} x_{i t}+\left(D_{i t} x_{i t}\right) \gamma_{i}+\mathrm{v}_{i t} \\
x_{i t}=x_{i t-1}+w_{i t}
\end{gathered}
$$

The cointegrating coefficients are forecasted by the AMG (Augmented Mean Group) estimator of Eberhardt and Teal [49] which considers the presence of crosssectional dependence and heterogeneity, and figures the panel and cross-sectional coefficients. The panel coefficient is figured through weighting the average values of the cross-sections' coefficients. Furthermore, the AMG estimator regards the common factors and dynamic effects of the variables, generates efficient results for the unbalanced panels, and may be employed in case of endogeneity problem [50]. The AMG estimator separates the variables as follows:

$$
\begin{gathered}
y_{i t}=\beta_{i}^{1} x_{i t}+u_{i t} \\
u_{i t}=\alpha_{i}+\lambda_{i}^{1} f_{t}+\varepsilon_{i t}(i=1 \ldots N, \quad t=1 \ldots T, \\
m=1 \ldots k)
\end{gathered}
$$

$x_{m i t}=\pi_{m i}+\delta_{m i}^{1} g_{m t}+\rho_{1 m i} f_{1 m t}+\cdots,+\rho_{n m i} f_{n m t}+v_{i t}$

$$
f_{t}=\tau^{1} f_{t-1}+\varepsilon_{i t} \text { ve } g_{t}=\Psi^{1} g_{t-1}+\Omega_{i t}
$$

... $x_{i t}$ denotes the vector of observable covariates, $f_{t}$ and $g_{t}$ are the unobserved common factors, and the $\lambda_{i}$ are the country-specific factor loadings in the above equations.

Lastly, the reciprocal interaction among international tourism, real GDP, and $\mathrm{CO}_{2}$ emissions was examined with the Dumitrescu and Hurlin [51] causality test considering the presence of heterogeneity and better performance under cross-sectional dependency.

\section{Results and Discussion}

In the applied analysis section of the study, first pretests of cross-sectional dependence and heterogeneity were conducted to specify the right econometric tests. The entity of cross-sectional dependence was examined with LM test of Breusch and Pagan [52], LM adj. test of Pesaran et al. [53] and LM CD test of Pesaran [54], and the test consequences are reported in Table 3. The null hypothesis of cross-sectional independence was denied at the $1 \%$ significance level. The presence of crosssectional dependencies among the series means that a shock occurring in a country in the sample affects the other countries in the panel differently. Furthermore, the entity of cross-sectional dependence among the 
Table 3. Results of cross-sectional dependency tests.

\begin{tabular}{|c|c|c|}
\hline Test & Test statistic & P value \\
\hline LM & 175.9 & 0.0000 \\
\hline LM adj. & 33.96 & 0.0000 \\
\hline LM CD & 9.137 & 0.0000 \\
\hline
\end{tabular}

Source: Authors' own elaboration based on cross-sectional dependency tests' results.

three series dictated us to utilize second generation tests regarding cross-sectional dependence.

The slope coefficients' homogeneity was examined with the adjusted delta tilde test of Pesaran and Yamagata [55] after investigation of cross-sectional dependence and test consequences, as reported in Table 4. The null hypothesis of homogeneity was rejected at the $1 \%$ significance level. Therefore, the slope coefficients of the cointegration equation were found to be heterogeneous. The tests results directed us to use an estimator considering heterogeneity.

The integration level of the series is important for the selection of the right cointegration test and in turn the reliability of the findings. In the study, the stationarity analysis of the study variables was examined with the Pesaran [56] CIPS (Cross-sectionally augmented IPS [57] unit root test taking note of cross-sectional dependence, and the test consequences are reported in Table 5. The test consequences uncovered that all the series were not stationary at the level, because the null hypothesis in favor of unit root presence was accepted considering their probability values. However the null hypothesis was rejected at 5\% significance level after the unit root test with the first differenced values of the series. So all the series were revealed to be I(1).

The cointegration relationship among $\mathrm{CO}_{2}$ emissions, international tourism, and real GDP was tested by Westerlund and Edgerton [48] cointegration test with structural breaks, considering the existence of crosssectional dependence and structural breaks in the study period and the test consequences are reported in Table 6 . The null hypothesis of no cointegration relationship was rejected at $5 \%$ significance level for three models of no shift, level shift, and regime shift. As a result, we found a significant long run relationship among the series. The significant cointegration relationship

Table 4. Results of homogeneity tests.

\begin{tabular}{|c|c|c|}
\hline Tests & Test statistic & P value \\
\hline$\tilde{\Delta}$ & 12.755 & 0.000 \\
\hline$\tilde{\Delta}_{\text {adj. }}$ & 13.916 & 0.000 \\
\hline
\end{tabular}

Source: Authors' own elaboration based on homogeneity tests' results.
Table 5. Results of CIPS unit root test

\begin{tabular}{|c|c|c|}
\hline Variables & Constant & Constant + Trend \\
\hline LCO & 2.642 & 0.570 \\
\hline D(LCO) & $-3.353 * * *$ & $-1.423 *$ \\
\hline LTOURISM & -2.764 & -0.979 \\
\hline D(LTOURISM) & $-2.664 * * *$ & $-1.697 * *$ \\
\hline LGDP & 0.014 & -0.231 \\
\hline D(LGDP) & $-2.799 * * *$ & $-0.971 *$ \\
\hline
\end{tabular}

Source: Authors' own elaboration based on unit root test results.

Optimum lag length was specified as 2 taking notice of Schwarz information criterion.

$* * *, * * * *$ indicated that it is respectively significant at $1 \%$, $5 \%$ and $\% 10$.

means that certain linear combinations of the series are stationary, although each individual component of a multivariate time series are not stationary. Furthermore, the dates of structural breaks in Table 6 revealed the global financial crisis, Eurozone sovereign debt crisis and Turkey's 2001 crisis had significant effects on the relationship among the series.

The panel and cross-sectional cointegrating coefficients were forecast by the AMG estimator of Eberhardt and Teal [49] regarding both cross-sectional dependence and heterogeneity; the estimation results are reported in Table 7. The estimations disclosed real GDP positively affected $\mathrm{CO}_{2}$ emissions on the overall panel, but international tourism had no significant effects on $\mathrm{CO}_{2}$ emissions. So, increases in economic output raised $\mathrm{CO}_{2}$ emissions in the long run.

However, the cross-sectional cointegration coefficients revealed that international tourism positively affected $\mathrm{CO}_{2}$ emissions in Italy and Slovenia. In other words, increases inbound tourism raised $\mathrm{CO}_{2}$ emissions in Italy and Slovenia in the long run. On the other side, real GDP positively affected $\mathrm{CO}_{2}$ emissions in Croatia, Cyprus, Greece, Italy, North Macedonia, Portugal, Spain, and Turkey in the long run. The largest environmental degradation by economic production was seen in Spain and Portugal, then North Macedonia, Italy, and Croatia. The positive impact of international tourism on $\mathrm{CO}_{2}$ emissions was found to be relatively weaker when compared with the impact of real GDP on $\mathrm{CO}_{2}$ emissions.

The theoretical and empirical literature on the nexus of tourism-environment reveals that a positive or negative influence of tourism on $\mathrm{CO}_{2}$ emissions is possible. In the study, we discovered that international tourism had no statistically significant effect on $\mathrm{CO}_{2}$ emissions in most of the countries, but tourism weakly raised $\mathrm{CO}_{2}$ emissions only in high-income economies of Slovenia and Italy. The finding indicates that Mediterranean European countries eliminated the negative environmental effects of increases in 
Table 6. Estimation of the cointegration coefficients.

\begin{tabular}{|c|c|c|c|c|}
\hline Model & $Z \varphi(N)$ & $P$ value & $Z \tau(N)$ & $P$ value \\
\hline No shift & -1.878 & 0.030 & -2.181 & 0.015 \\
\hline Level shift & -1.035 & 0.050 & -0.192 & 0.024 \\
\hline Regime shift & -2.708 & 0.003 & -2.447 & 0.007 \\
\hline Country & \multicolumn{2}{|c|}{ Structural breaks (level shift) } & \multicolumn{2}{|c|}{ Structural breaks (regime shift) } \\
\hline Croatia & \multicolumn{2}{|c|}{2011} & \multicolumn{2}{|c|}{2011} \\
\hline Cyprus & \multicolumn{2}{|c|}{2012} & \multicolumn{2}{|c|}{2012} \\
\hline Greece & \multicolumn{2}{|c|}{2012} & \multicolumn{2}{|c|}{2012} \\
\hline Israel & \multicolumn{2}{|c|}{2012} & \multicolumn{2}{|c|}{2012} \\
\hline Italy & \multicolumn{2}{|c|}{2008} & \multicolumn{2}{|c|}{2012} \\
\hline North Macedonia & \multicolumn{2}{|c|}{2001} & \multicolumn{2}{|c|}{1998} \\
\hline Portugal & \multicolumn{2}{|c|}{2009} & \multicolumn{2}{|c|}{2009} \\
\hline Slovenia & \multicolumn{2}{|c|}{2013} & \multicolumn{2}{|c|}{2013} \\
\hline Spain & \multicolumn{2}{|c|}{2008} & \multicolumn{2}{|c|}{2012} \\
\hline Turkey & \multicolumn{2}{|c|}{2000} & \multicolumn{2}{|c|}{1999} \\
\hline
\end{tabular}

Source: Authors' own elaboration based on cointegration test results.

international tourism through coherent green policies. However, the significant findings for Italy and Slovenia contradicted with Dogan and Aslan [27], Paramati et al. [33], and Balsalobre-Lorente et al. [36]. We evaluated that the contradiction may be resulted from different study periods and estimators. On the other side, real GDP raised $\mathrm{CO}_{2}$ emissions in all the countries except

Table 7. Results of cointegration coefficients' estimation.

\begin{tabular}{|c|c|c|}
\hline \multirow{2}{*}{ Countries } & \multicolumn{2}{|c|}{ Coefficients } \\
\cline { 2 - 3 } & TOURISM & GDP \\
\hline Croatia & -0.0407131 & $0.8303971 * * *$ \\
\hline Cyprus & 0.0317651 & $0.8119142 * * *$ \\
\hline Greece & 0.0335223 & $0.4733397 * * *$ \\
\hline Israel & -0.0169069 & 0.6009993 \\
\hline Italy & $0.1055025 * *$ & $0.8604907 * * *$ \\
\hline North Macedonia & -0.0157873 & $0.9360215^{*}$ \\
\hline Portugal & -0.1839001 & $1.014427 * *$ \\
\hline Slovenia & $0.1347397 * * *$ & 0.3261503 \\
\hline Spain & -0.0673256 & $1.038071 * * *$ \\
\hline Turkey & -0.0264264 & $0.5793928 * * *$ \\
\hline Panel & -0.004553 & $0.7471203 * * *$ \\
\hline
\end{tabular}

Source: Authors' own elaboration based on AMG estimation results.

$* * *, * * *$ indicated that it is respectively significant at $1 \%$, $5 \%$ and $\% 10$.
Israel and Slovenia. Normally, our prediction on the effect of real GDP on $\mathrm{CO}_{2}$ emissions was negative considering that two countries (North Macedonia, Turkey) are upper-middle-income economies and the rest are high-income economies according to World Bank [58]. Nevertheless, real GDP positively affected $\mathrm{CO}_{2}$ emissions in Croatia, Cyprus, Greece, Italy, North Macedonia, Portugal, Spain, and Turkey. This can be resulted from that the countries have not reached the threshold level of economic development for the reversal of environmental effect of growth. In the light of the findings, transition to relatively greener production by the countries has become unavoidable. Furthermore, regulatory framework exhibits importance for green performance of economic units (e.g. see Simões and Marques [59] and Marques et al. [60]).

The causal interaction among international tourism, real GDP, and $\mathrm{CO}_{2}$ emissions was tested by

Table 8. Results of causality analysis.

\begin{tabular}{|c|c|c|c|}
\hline Null Hypothesis: & W-Stat. & Zbar-Stat. & Prob. \\
\hline DLTOURISM $\nrightarrow$ DLCO & 0.73004 & -0.70791 & 0.4790 \\
\hline DLCO $\nrightarrow$ DLTOURISM & 1.10903 & -0.01574 & 0.9874 \\
\hline DLGDP $\nrightarrow$ DLCO & 3.71228 & 4.73877 & $2 . E-06$ \\
\hline DLCO $\nrightarrow$ DLGP & 0.44955 & -1.22019 & 0.2224 \\
\hline DLGDP $\nrightarrow$ DLTOURISM & 1.42830 & 0.56738 & 0.5705 \\
\hline DLTOURISM $\nrightarrow$ DLGDP & 2.30913 & 2.17608 & 0.0295 \\
\hline
\end{tabular}

Source: Authors' own elaboration based on causality test results. 
the Dumitrescu and Hurlin [51] causality test, and test results are reported in Table 8 . The results revealed a unilateral causality from real GDP to $\mathrm{CO}_{2}$ emissions and from international tourism to real GDP. So, international tourism had no significant effects on $\mathrm{CO}_{2}$ emissions in the short run, but real GDP had significant influence on $\mathrm{CO}_{2}$ emissions in the short run.

\section{Conclusions}

International tourism has considerably expanded and become one of the main export category with the contribution of liberalization and globalization processes and technological developments and cost reduction in travelling. The relevant literature indicated that researchers have generally focused on economic effects of international tourism, although international tourism has social, cultural, and environmental implications for the societies. Therefore, we analyzed the short and long run environmental effects of international tourism together with real GDP on $\mathrm{CO}_{2}$ emissions in sample of Mediterranean European countries through second generation cointegration test and causality test.

The short run analysis through causality test disclosed no significant effects of international tourism on $\mathrm{CO}_{2}$ emissions, but real GDP had a significant impact on $\mathrm{CO}_{2}$ emissions in the short run, international tourism also had a significant impact on real GDP in the short run. On the other side, long run analysis through second generation cointegration test with structural breaks revealed that international tourism raised $\mathrm{CO}_{2}$ emissions weakly in Italy and Slovenia in the long run. The empirical analysis revealed that international tourism had no significant effects on $\mathrm{CO}_{2}$ emissions in short and long run in most of the countries in the sample. We can judge from the findings that Mediterranean European countries employ adequate green policies in tourism sector to eliminate the negative environmental effects of the expanding international tourism and also consider environmental issues in the touristic and infrastructure investments. On the other side, real GDP raised $\mathrm{CO}_{2}$ emissions in all the countries except Israel and Slovenia in the long run. So economic output led the environmental degradation in Spain, Portugal, North Macedonia, Italy, Croatia, Cyprus, Turkey, and Greece from the highest to lowest in terms of negative effect size in the long run. The negative environmental effects of economic output oblige the countries to adapt a relatively greener national regulatory framework and production, improve energy efficiency and renewable energy use as possible. Future studies can be conducted on the channels through which international tourism and economic output affects the environment.

\section{Conflict of Interest}

The authors declare no conflict of interest.

\section{References}

1. World Tourism Organisation (UNWTO). UNWTO World Tourism Barometer and Statistical Annex, January 2020. World Tourism Barometer (Vol. 18), 2020.

2. World Travel Organization. International Tourism Highlights 2019 Edition, 2019.

3. OECD. OECD Tourism Trends and Policies 2020-Policy highlights, 2020.

4. FRENT C. An overview on the negative impacts of tourism. Revista de Turism:Studii si Cercetari in Turism, 22, 32, 2016.

5. TROANCA D. The impact of tourism development on urban environment. Studies in Business and Economics, 7 (3), 160, 2012.

6. STERN D.I. The environmental Kuznets curve. International Society for Ecological Economics Internet Encyclopedia of Ecological Economics, 2003.

7. VANHOVE N. Tourism and employment. International Journal of Tourism Management, 2 (3), 162, 1981.

8. BALAGUER J., CANTAVELLA-JORDÁ M. Tourism as a long-run economic growth factor: The Spanish case. Applied Economics, 34 (7), 877, 2002.

9. PERLES-RIBES J.F., RAMÓN-RODRÍGUEZ A.B., RUBIA A., MORENO-IZQUIERDO L. Is the tourismled growth hypothesis valid after the global economic and financial crisis? The case of Spain 1957-2014. Tourism Management, 61, 96, 2017.

10. ALI Q., KHAN M.T.I., KHAN M.N.I. Dynamics between financial development, tourism, sanitation, renewable energy, trade and total reserves in 19 Asia cooperation dialogue members. Journal of Cleaner Production, 179, 114, 2018.

11. PAN X.M., DOSSOU T.A. M. The relationship between tourism and sustainable economic growth in the Republic of Benin. Current Issues in Tourism, 23 (7), 1, 2020.

12. RASHEED R., MEO M.S., AWAN R.U., AHMED F. The impact of tourism on deficit in balance of payments of Pakistan: an application of bounds testing approach to cointegration. Asia Pacific Journal of Tourism Research, 24 (4), 325, 2019.

13. FU X., RIDDERSTAAT J., JIA H. (Chenge). Are all tourism markets equal? Linkages between market-based tourism demand, quality of life, and economic development in Hong Kong. Tourism Management, 77, 2020.

14. LV Z. Does tourism affect the informal sector? Annals of Tourism Research, 80, 2020.

15. WAMBOYE E.F., NYARONGA P.J., SERGI B.S. What are the determinant of international tourism in Tanzania? World Development Perspectives, 17 (C), 2020.

16. DRITSAKIS N. Tourism as a long-run economic growth factor: An empirical investigation for Greece using causality analysis. Tourism Economics, 10 (3), 305, 2004.

17. FAYISSA B., NSIAH C., TADASSE B. Impact of tourism on economic growth and development in Africa. Tourism Economics, 14, 1, 2008.

18. KAREEM O.I. Tourism - exports and economic growth in africa. Paper Presented at the $13^{\text {th }}$ African Econometrics Society (AES) conference in Pretoria, South Africa. Retrieved from http://citeseerx.ist.psu.edu/viewdoc/downlo ad?doi=10.1.1.590.1483\&rep=rep1\&type=pdf, 2008.

19. BELLOUMI M. The relationship between tourism receipts, real effective exchange rate and economic growth in Tunisia. International Journal of Tourism Research, 12 (5), 550, 2010. 
20. NISSAN E., GALINDO M.A., MÉNDEZ M.T. Relationship between tourism and economic growth. Service Industries Journal, 31 (10), 1567, 2011.

21. JAYATHILAKE P.M.B. Tourism and economic growth in Sri Lanka: evidence from cointegration and causality analysis. International Journal of Business, Economics and Law, 2 (2), 22, 2013.

22. ALAM M.S., PARAMATI S.R. The impact of tourism on income inequality in developing economies: Does Kuznets curve hypothesis exist? Annals of Tourism Research, 61, 111, 2016.

23. NENE G., TAIVAN A. Causality between tourism and economic growth: Evidence from Sub Saharan Africa (SSA). The Journal of Developing Areas, 51 (2), 155, 2017.

24. LEE J. W., BRAHMASRENE T. Investigating the influence of tourism on economic growth and carbon emissions: Evidence from panel analysis of the European Union. Tourism Management, 38, 69, 2013.

25. ÖZCAN C.C., GERÇEKER M., ÖZMEN İ. Turizm ve çevre ilişkisinin ekonometrik bir analizi. In ICPESS 2016-ISTANBUL, 24-26 August 2016 (pp. 125-135), 2011.

26. AKADIRI S., AKADIRI A.C., ALOLA U.V. Is there growth impact of tourism? Evidence from selected small island states. Current Issues in Tourism, 22 (12), 1480, 2017.

27. DOGAN E., ASLAN A. Exploring the relationship among $\mathrm{CO}_{2}$ emissions, real GDP, energy consumption and tourism in the EU and candidate countries: Evidence from panel models robust to heterogeneity and cross-sectional dependence. Renewable and Sustainable Energy Reviews, 77 (March), 239, 2017

28. KATIRCIOGLU S.T. International tourism, energy consumption, and environmental pollution: The case of Turkey. Renewable and Sustainable Energy Reviews, 36, 180, 2014.

29. EYUBOGLU K., UZAR U. The impact of tourism on $\mathrm{CO}_{2}$ emission in Turkey. Current Issues in Tourism, 23 (13), 1631, 2020.

30. RASEKHI S., KARIMI S., MOHAMMADI S. Environmental impacts of tourism: A case study of selected developing and developed countries. Journal of Tourism Planning and Development, 5 (16), 20, 2016.

31. ZHANG L., GAO J. Exploring the effects of international tourism on China's economic growth, energy consumption and environmental pollution: Evidence from a regional panel analysis. Renewable and Sustainable Energy Reviews, 53, 225, 2016.

32. ZAMAN K., SHAHBAZ M., LOGANATHAN N., RAZA S.A. Tourism development, energy consumption and Environmental Kuznets Curve: Trivariate analysis in the panel of developed and developing countries. Tourism Management, 54, 275, 2016.

33. PARAMATI S.R., ALAM M.S., CHEN C.F. The effects of tourism on economic growth and $\mathrm{CO}_{2}$ emissions: A comparison between developed and developing economies. Journal of Travel Research, 56 (6), 712, 2017.

34. AKADIRI S.S., LASISI T.T., UZUNER G., AKADIRI A. C. Examining the causal impacts of tourism, globalization, economic growth and carbon emissions in tourism island territories: bootstrap panel Granger causality analysis. Current Issues in Tourism, 23 (4), 470, 2018.

35. SGHAIER A., GUIZANI A., BEN JABEUR S., NURUNNABI M. Tourism development, energy consumption and environmental quality in Tunisia, Egypt and Morocco: a trivariate analysis. GeoJournal, 84 (3), 593, 2019.
36. BALSALOBRE-LORENTE D., DRIHA O.M., SHAHBAZ M., SINHA A. The effects of tourism and globalization over environmental degradation in developed countries. Environmental Science and Pollution Research, 27 (7), 7130, 2020.

37. KOÇAK E., ULUCAK R., ULUCAK Z.Ş. The impact of tourism developments on $\mathrm{CO}_{2}$ emissions: An advanced panel data estimation. Tourism Management Perspectives, 33, 2020.

38. AL-TORKISTANI H.M., SALISU M.A., MAIMANY K.A. Modeling a sustainable Saudi Arabian economy: The real issues. International Journal of Sustainable Development and World Ecology, 23 (2), 186, 2016.

39. LIU Y., YAN B., ZHOU Y. Urbanization, economic growth, and carbon dioxide emissions in China: A panel cointegration and causality analysis. Journal of Geographical Sciences, 26 (2), 131, 2016.

40. APERGIS N., CHRISTOU C., GUPTA R. Are there Environmental Kuznets Curves for US state-level $\mathrm{CO}_{2}$ emissions? Renewable and Sustainable Energy Reviews, 69, 551, 2017

41. AYE G.C., EDOJA P.E. Effect of economic growth on $\mathrm{CO}_{2}$ emission in developing countries: Evidence from a dynamic panel threshold model. Cogent Economics and Finance, 5, 1, 2017.

42. ALTINTAŞ H., KASSOURI Y. Is the environmental Kuznets Curve in Europe related to the per-capita ecological footprint or $\mathrm{CO}_{2}$ emissions? Ecological Indicators, 113 (January), 2020.

43. SARKODIE S.A., OZTURK I. Investigating the Environmental Kuznets Curve hypothesis in Kenya: A multivariate analysis. Renewable and Sustainable Energy Reviews, 117 (October 2019), 109481, 2020.

44. SHAHEEN A., SHENG J., ARSHAD S., SALAM S., HAFEEZ M. The dynamic linkage between income, energy consumption, urbanization and carbon emissions in Pakistan. Polish Journal of Environmental Studies, 29 (1), 267, 2020.

45. BP. Statistical Review of World Energy Statistical Review of World. Retrieved from https://www.bp.com/en/global/ corporate/energy-economics/statistical-review-of-worldenergy/downloads.html (accessed on 12.01.2020)

46. WORLD BANK. International tourism, receipts (current US\$). Retrieved from https://data.worldbank.org/indicator/ ST.INT.RCPT.CD (accessed on 12.01.2020)

47. WORLD BANK. GDP (constant 2010 US\$). Retrieved from https://data.worldbank.org/indicator/NY.GDP.MKTP. KD (accessed on 12.01.2020)

48. WESTERLUND J., EDGERTON D.L. A simple test for cointegration in dependent panels with structural breaks. Oxford Bulletin of Economics and Statistics, 70 (5), 665, 2008.

49. EBERHARDT M., TEAL F. Productivity analysis in global manufacturing production. Economics Series Working Papers, 515, 2010.

50. EBERHARDT M., BOND S. Cross-section dependence in nonstationary panel models: a novel estimator. MPRA (Munich Personal RePEc Archive). Retrieved from https:// mpra.ub.uni-muenchen.de/17692/, 2009.

51. DUMITRESCU E.I., HURLIN C. Testing for Granger non-causality in heterogeneous panels. Economic Modelling, 29 (4), 1450, 2012

52. BREUSCH T.S., PAGAN A.R. The lagrange multiplier test and its applications to model specification in econometrics. The Review of Economic Studies, 47 (1), $239,1980$. 
53. ESARAN M.H., ULLAH A., YAMAGATA T. A biasadjusted LM test of error cross-section independence. Econometrics Journal, 11 (1), 105, 2008.

54. PESARAN M.H. General diagnostic tests for cross section dependence in panels (No. 1229). Munich, 2004.

55. PESARAN M.H., YAMAGATA T. Testing slope homogeneity in large panels. Journal of Econometrics, 142, 50, 2008.

56. PESARAN M.H. A simple panel unit root test in the presence of cross-section dependence. Journal of Applied Econometrics, 22, 265, 2007.

57. IM K.S., PESARAN M.H., SHIN Y. Testing for unit roots in heterogeneous panels. Journal of Econometrics, 115, 53, 2003.
58. WORLD BANK. Country and Lending Groups. Retrieved from https://datahelpdesk.worldbank.org/knowledgebase/ articles/906519-world-bank-country-and-lending-groups (accessed on 12.04. 2020)

59. SIMÕES P., MARQUES R.C. Influence of regulation on the productivity of waste utilities. What can we learn with the Portuguese experience? Waste Management, 32, 1266, 2012.

60. MARQUES R.C., SIMÕES P., PIRES J.S. Performance benchmarking in utility regulation: the worldwide experience. Polish J. of Environ. Stud., 20 (1), 125, 2011. 
